\title{
Trends in the Distribution of Stock Ownership
}





\title{
Trends in the Distribution of Stock Ownership
}

\author{
by Edwin Burk Cox \\ Associate Professor of Statistics \\ Boston University
}

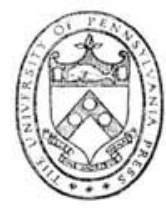

Philadelphia

University of Pennsylvania Press 
(C) 1963 by the Trustees of the University of Pennsylvania Published in Great Britain, India, and Pakistan by the Oxford University Press London, Bombay and Karachi

Library of Congress Catalog Card Number: 63-7855

7355

Printed in Great Britain

by Charles Birchall \& Sons, Ltd., Liverpool and London 
To My Mother and Father 
